\title{
IRANIAN THEMES IN THE POETRY OF CLAUDIAN
}

\begin{abstract}
In comparison with other Latin poets Claudian reached for motifs connected with the Iranian world quite frequently. He made use of them throughout the entire corpus of his works, both in political and "minor" poems. In treatment of these issues he appeared as a careful reader and follower of previous poets (esp. Vergil, Lucan and Statius) but on the other hand he introduced some new motifs and transformed the existent ones. My study aims at subjecting references to the Iranian themes to closer scrutiny so as to distinguish recurring patterns and to show the poet's ability in exploiting them skilfully in line with his artistic purposes.
\end{abstract}

Key words. - Claudian, Latin poetry, Late Antiquity, Iran in Latin poetry, Roman-Persian relations, Ancient Iran.

The works of Claudian (floruit 395-404) are usually perceived as the greatest achievement of Late Antique Latin poetry. In the last decades of intensive research interest in this period the opinions on the oeuvre of this poet were reassessed giving rise to better understanding of his poems and environment in which he was active. Scholars have already written a lot on different aspects of Claudian's poetry, covering topics of intertextuality, genre or political history. ${ }^{1}$ However, the perception of different cultures and their depiction in his poems still awaits a thorough analysis. ${ }^{2}$ In my paper I would like to focus on one particular group, i.e. Iranians. The Roman-Persian (and earlier RomanParthian) relations were undoubtedly one of the most important factors in the entire Roman politics and found resonance in the Latin poetry, especially in the Augustan age. Furthermore, due to great importance attached to Persians in Greek culture the poet had an opportunity of taking advantage of a number of topoi connected with Achaemenid

${ }^{1}$ On Claudian see e.g.: Cameron 1970; Döpp 1980; Garambois-Vasquez 2007; Guipponi-Gineste 2010; Ware 2012; Coombe 2018.

${ }^{2}$ The lengthy book of Chauvot has a chapter on Claudian but it is, unfortunately, much too short for the importance of this poet and for the complexity of his image of nonRomans. What is more, the author focuses on Germans and makes use of very few works from the scholarship on this poet - Chauvot 1998: 329-342. 
Persia which after all influenced greatly the image of Parthian and Sasanian empires. Finally, Claudian mentioned Persian themes quite often in comparison with other Latin poets both of his and previous ages. That being so, carrying out an analysis of references to the Iranian world ${ }^{3}$ in his poetry seems fully justified. ${ }^{4}$

Before proceeding to the analysis, some preliminary remarks are to be made. Firstly, in the Latin poetry the Iranian world is usually treated in a negative light as hostile to Rome. Thence, in its description we encounter a number of pejorative stereotypes referring to morality and way of life and such references usually assume the opposition and hostility between Romans and Iranians. ${ }^{5}$ Secondly, the literary tradition had a great impact on Latin poets, bringing them to explore older texts and making use of the already existing image of the Iranian world treated as a part of a greater whole, i.e. generalized world of the East. ${ }^{6}$ The Greek tradition based on the experience of the Persian Wars in $5^{\text {th }}$ century $\mathrm{BC}$ was particularly strong and pervasive, giving rise to mentions of Xerxes' invasion and slavish obedience of the Orientals to their monarchs. These two observations remain in effect with regard to the poetry of Claudian who was active in the Western part of the Empire and for obvious reasons could not have a detailed first-hand knowledge of the Iranian issues, by dint of which he was bound to make an extensive use of previous authors who touched those topics. ${ }^{7}$

In my paper I would like to discuss Claudian's use of Iranian themes, dividing them into three subcategories. First, I am going to handle the vague references to the future Oriental conquests in political poetry. They make up an important part of the praise ascribed to the honorands and are recurring pattern, especially in the panegyrics. The second group to be analysed are references to the history of the Iranian world from Achaemenid times to the end of the $4^{\text {th }}$ century

${ }^{3}$ The notion of the Iranian world is used in this paper to cover all the references to Iranian peoples and regions they inhabited. Persians were only one of those peoples. Classical authors used to treat interchangeably the names Persae, Parthi and Medi and to merge associations that - strictly speaking - should be ascribed to only one of those people (e.g. so-called "Parthian shot" was a part of Parthian, not Persian way of fighting). Claudian followed suit with one interesting exception.

${ }^{4}$ The following paper is based on chapter dedicated to Claudian's poetry in my doctoral dissertation (in Polish): Babnis 2020b: 423-470.

${ }^{5}$ See e.g. Paratore 1966; Rosivach 1984; Isaac 2004: 371-380; Lerouge 2007 (esp. 282-321). Obviously, there are exceptions to this rule, e.g. the catalogue of troops supporting Theodosius the Great in his war against the usurper Eugenius in which we encounter a number of Eastern peoples, i.a. Parthians and Medians (Claud. III Cons. 65-72). Although unhistorical, this image serves to show the general support to Theodosius given by the whole world and Iranians are only a small part of the entire catalogue. This image is repeated with some changes in panegyric on Stilicho's consulship (Claud. Stil. I 154161), where it serves as a symbol of unity - Chauvot 1998: 336.

${ }^{6}$ Cf. Hall 1989; Georges 1994.

${ }^{7}$ On the other hand, Claudian was a source of inspiration for later poets, especially Sidonius, in describing the Iranian world - Kelly 2013; Babnis 2021. 
AD. Sometimes they have a political dimension too, however some of them should be seen also as moral examples. Finally, I am going to discuss some minor references and similes that are included in the narration as mere ornaments. Nevertheless, they are also worth analysing, for they show some strong and deeply-rooted associations related to the Iranian world and let us notice some aspects normally hidden under the layer of political imagery.

The importance of the role of Claudian as a propagandist of Stilicho cannot be denied and overemphasised. It found particular expression in five panegyrics celebrating the consulships of Honorius (396, 398, 404 AD), Manlius Theodorus (399 AD) and Stilicho (400 $\mathrm{AD}$ ). In these pieces Claudian made use of the rules of prosaic panegyric codified e.g. in the work of Menander Rhetor and applied in the Roman literature in so called "Panegyrici Latini". Claudian's innovation consisted in applying this scheme to hexameter and in linking it with epic narration. ${ }^{8}$ One of the oft-repeated motifs of his panegyrics was the announcement of future conquests in the East. It appeared usually in the epilogue where it took shape of catalogue of geographic and ethnic proper names. A prime example of such a catalogue are the last verses of the panegyric on the third consulship of Honorius:

Iam video Babylona rapi Parthumque coactum
Non ficta trepidare fuga, iam Bactra teneri
Legibus et famulis Gangen pallescere ripis
Gemmatosque humilem dispergere Persida cultus.
Ite per extremum Tanaim pigrosque Triones,
Ite per ardentem Libyam, superate vapores
Solis et arcanos Nili deprendite fontes,
Herculeum finem, Bacchi transcurrite metas:
Vestri iuris erit, quidquid complectitur axis,
Vobis Rubra dabunt pretiosas aequora conchas,
Indus ebur, ramos Panchaia, vellera Seres.
(Claud. III Cons. 201-211)

The poet set the directions of Roman expansion under the joint rule of Honorius and his brother Arcadius. Therefore, he included a number of exotic proper names from different parts of the world. Such an enumeration, being a sign of poesis docta, enabled the poet to reach for the names known from earlier authors. ${ }^{9}$ In this catalogue we encounter several names connected with the Persian empire. The poet started from the mention of Babylon, a symbol of the whole Persian Mesopotamia. Since Romans bordered Persia in this very region they treated it more often than the others. In addition, Ctesiphon, the capi-

\footnotetext{
${ }^{8}$ See esp. Schindler 2009.

${ }^{9}$ Case in point is the last line with a clear reference to Vergil (Verg. Georg. II 136$139)$.
} 
tal of the empire, was located right there. ${ }^{10}$ Babylon and Bactra (capital of the satrapy of Bactria in modern-day Afghanistan) were names frequently used in connection with Alexander's campaign, which added another point to the praise due to juxtaposition of the honorand with the greatest conqueror ever born. ${ }^{11}$ In this passage Claudian put an emphasis on natural riches of given lands, adding some economic incentive to military expansion. To Persia he ascribed precious stones (gemmatosque ... cultus, 1. 204), referring thus to the opinion on the particular abundance of this resource in Persia. ${ }^{12}$ It can be treated as a reflection of the old tradition of Persian wealth. Tradition being a result of Greek influence on the Latin literature. Another important feature of the entire passage is a belief (expressed twice: 1. 202-203, 209) that the East should be subordinated to the Roman law. This - so to speak - proto-orientalist sign of the Roman mission civilisatrice is another argument for the conquest. ${ }^{13}$

In the above-mentioned catalogue Iranian themes are treated in a generalised way. They make up a mere part of a greater whole, the world awaiting to be conquered. However, one element is really distinctive and shows a peculiarity of the Iranian world. It is the mention of the tactics of fake retreat used widely by the Parthian army. The phrase Parthumque coactum / Non ficta trepidare fuga (1. 201-202) refers unequivocally to this way of fighting but from a different than usual perspective. This time Parthians should really flee for fear of the Roman power. Describing Parthians (and then Persians) the Latin poets made an extensive use of this image and horse and bow were their essential attributes. Such a perception stemmed from the memory of Roman defeats in wars with Parthia, especially to the great disaster of Carrhae (53 BC). Although this respect for Parthian martial skills was overtly expressed in the Latin literature, it was mixed with a contradictory opinion of Orientals' effeminacy and cowardice. ${ }^{14}$ However, in this passage mention of fear (trepidare, 1. 202) ought to be treated not

${ }^{10}$ Interestingly, the name Ctesiphon is almost totally absent from the Roman poetry despite the great significance of this city. Only Sidonius mentioned it twice (Sid. Carm. II 451; Sid. Epist. IX 13, 5, 1. 21). Partially the reason for this absence is the metrical structure of this name $\left(-\mathrm{U}_{-}\right)$which does not suit hexameter verse - Babnis 2020b: 455

${ }^{11}$ So called imitatio Alexandri was an essential factor in the Roman eastern politics from the $1^{\text {st }}$ century BC. Hence it was referred to in the Latin poetry providing opportunity to mention Iranian themes. See Kühnen 2008 (unfortunately, the author leaves Late Antiquity beyond the scope of her study).

12 This opinion can be found both in prose and poetry of the Late Antiquity, cf. Solin. 37, 11; Claud. Rapt. II 94; Dracont. Laud. Dei I 321.

${ }^{13}$ This element can be noticed already in Augustan poetry, when poets fairly often referred to giving laws to the barbarians, cf. Per populos dat iura viamque adfectat Olympo (Verg. Georg. IV 562); triumphatisque possit / Roma ferox dare iura Medis (Hor. Carm. III 3, 39-40); Tigris et Euphrates sub tua iura fluent (Prop. III 4, 4). This mixture of imperial conquest and civilizing mission of Rome survived up to the Late Antiquity Brodka 1998: 107.

${ }^{14}$ Lerouge 2007: 305-321; Babnis 2020a: 11. 
as a reference to Parthian innate cowardice, but rather as another symbol of Roman might. In the absence of military success in relations with Parthians and Persians Latin poets mentioned frequently their fear and respect towards Rome. Claudian explored this idea so as not to exaggerate too much in his praise of Honorius: the real conquests in the East (even in cooperation with Arcadius) were impossible in 396, so emphasising the fear of Persians was more convenient in terms of probability. In this way the poet followed in the footsteps of Augustan authors who had to show that after Roman-Parthian treaty of 20 BC Romans subordinated Parthians despite they were unconquered, so they put emphasis on their alleged fear or respect for Augustus in order to show that they too acknowledge Roman power. ${ }^{15}$

Although "In Rufinum" is an invective, not a panegyric, this poem contains similar announcement of future conquests in its epilogue. This time, however, the prophecy was delivered by the personification of Justice (1. 368-387), a motif frequently used in Claudian's oeuvre. The poet stated that great conquests in the East are going to happen, when Honorius comes of age. ${ }^{16}$ The golden age which, described in Vergilian manner in 1. 377-387, started after the death of the infernal character of Rufinus ${ }^{17}$ should be based on military triumph over Orientals:

Iamque aderit laeto promissus Honorius aevo

Nec forti genitore minor nec fratre corusco,

Qui subiget Medos, qui cuspide proteret Indos.

Sub iuga venturi reges; calcabitur asper

Phasis equo pontemque pati cogetur Araxes

(Claud. In Ruf. I 372-376)

Again Claudian made use of catalogue of proper names, but this time juxtaposed the names of peoples and rivers. Persia (referred to as Medi, in accordance with the Greek tradition) and India were mooted again as an easy prey for Rome ruled by Honorius. The emphasis was put on the issue of subordination which was shown the best in the vocabulary connected with the triumphal parade (subiget, iuga, calcabitur , 1. 374-375). ${ }^{18}$ It was a more direct way of depicting the power of Rome compared to the one in which Eastern monarchies were told to be just lands to conquer. A way of showing subordination which I find particularly interesting is the phrase pontemque pati cogetur Araxes (1.

${ }^{15}$ Cf. Babnis 2020b: 235-236.

${ }^{16}$ Stressing Honorius' minority enables Claudian to strengthen the audience's conviction that Stilicho ought to govern the Roman state. However, emperor's time was never to come, even when he came of age and later got rid of his omnipotent father in law in $408 \mathrm{AD}$.

${ }^{17}$ See esp. Ware 2012: 207-220 (Rufinus shown as a threat to the golden age).

${ }^{18}$ Cf. McCormick 1986: 35-130. 
376). Generally speaking, the Araxes was treated as a pars pro toto for Armenia, which was for centuries a bone of contention between Rome and Parthia/Persia. Undoubtedly, it should be seen against the background of Vergilian (Verg. Aen. VIII 728) and Statian (Stat. Silv. I 4, 79) intertext as the reassumption of the well-known motif, ${ }^{19}$ but also as another reference to the idea of mission civilisatrice. To tame the river known for its swiftness by bridging it meant again to introduce civilisation to the wilderness and to impose the Roman order upon barbarians.

Another reference to the lands under the Persian rule as the goal of the imperial expansion was included in the epilogue of the panegyric on the fourth consulship of Honorius (398 AD). With these lines the poet tried to placate the tense atmosphere between both parts of the Empire foretelling the offensive carried out in a joint effort of two brothers:

\section{Tempus erit, cum tu trans Rheni cornua victor, Arcadius captae spoliis Babylonos onustus \\ Communem maiore toga signabitis annum; Crinitusque tuo sudabit fasce Suebus, Ultima fraternas horrebunt Bactra secures. (Claud. IV Cons. 652-656)}

The poet made a symmetrical division of the land to conquer assigning Germany to Honorius and Persia to Arcadius. Admittedly, such a division seems obvious in terms of geography, but contrasts with the general tendency of panegyrical literature. Though the East was ascribed to Arcadius' sphere of influence the image of the Persian empire was shown in a way similar to that from the previous poems in which it had been to be conquered by Honorius. The proper names used in this passage are again Babylon and Bactra (with an allusive reference to Alexander) which are given typical association: the former with wealth, the latter with remoteness from Graeco-Roman world. ${ }^{20}$ Thus, such conquests should give Rome imperium sine fine (Verg. Aen. I 279). Persians (and Germans as well) may only await the Roman expansion. Both nations are perceived as symbols of greater wholes, i.e. the former of the Oriental world and the latter of the European Barba-

${ }^{19}$ On the river Araxes in Roman poetry see Babnis 2019 (esp. 30-36). In more general terms crossing of the border river is a direct symbol of subjugation of another land.

${ }^{20}$ If we carried out an analysis of the names of the cities of the Parthian/Persian empire referred to in the Roman poetry, we would notice that Babylon and Bactra are by a long margin the most common - Babnis 2020b: 547. One could suppose that this frequency stemmed both from the connection with the history of Alexander and from the fact that they marked out the extreme western and eastern parts of the empire. Bactra were seen as a world's end, whereas Babylon evoked associations with pre-Achaemenid times and the mysterious art of divination. 
ricum. On the whole, this is exactly the role ascribed to Persians in panegyrical passages of Claudian's poetry. ${ }^{21}$

Generally, the most frequently mentioned person from the history of the Iranian world was Xerxes, who led an expedition against Greece in $480 \mathrm{BC}^{22}$ Due to important place dedicated to this campaign in the "Histories" of Herodotus and due to the great impact of Persian wars on Greek civilization Xerxes became a symbol of human hubris as a transgressor of the natural order of things. ${ }^{23}$ The Latin poets had a particular fondness for mooting two extraordinary events from his campaign, i.e. crossing of Hellespont by his army and crossing the channel near the Athos Mountain by his fleet. ${ }^{24}$ Other aspects of this expedition were not referred to so often but in the passage from "In Rufinum" they are listed together:

\section{Haud aliter Xerxen toto simul orbe secutus Narratur rapuisse vagos exercitus amnes Et telis umbrasse diem, cum classibus iret Per scopulos tectumque pedes contemneret aequor. (Claud. In Ruf. II 120-123)}

In the long simile introduced by typical phrase haud aliter Claudian listed four spectacular motifs connected with the campaign of Xerxes. All of them were taken - though probably not directly - from the work of Herodotus. ${ }^{25}$ The poet made a reference to drinking rivers dry by the Persian army, to hiding sun with Persian arrows in the battle of Thermopylae and to two aforementioned crossings of Hellespont

${ }^{21}$ Other examples of such function, see e.g. Claud. Prob. et Olyb. 160-163; Claud. III Cons. 33-38; Claud. Gild. 28-36.

${ }^{22}$ Claudian did not fail to mention another Achaemenid king, Cyrus, who was paired with Croesus as symbol of wealth and kingship (Claud. In Ruf. I 198; Claud. In Eutr. I 214-215). As regards Sasanian kings, he made a reference to Wahram IV (giving him a "dynastic name", Sapor - Claud. In Eutr. II 481-482) and to unnamed king (Ardashir II or Shapur III) to whom Theodosius the Great had sent the diplomatic mission with Stilicho Claud. Stil. I 62-63). However, contrary to first Achaemenians, later kings virtually do not have an individual profile. Cf. Babnis 2020b: 544.

${ }^{23}$ Bridges 2015; Babnis 2020b: 542.

${ }^{24}$ Hellespont: Enn. fr. 369; Luc. II 672-674; Prop. II 1, 22. Athos: Catul. 66, 45-46; Iuv. X 174; Claud. In Ruf. I 335-336; Sid. Carm. II 509-510. Both crossings together: Lucr. III 1029-1034; Manil. V 49. The popularity of this motif stemmed partially from its use in rhetoric schools, as Lucian (Luc. Rh. pr. 18) clearly stated. Admittedly, Lucian referred to the Greek school but the situation in the Roman one was not much different in this respect..

${ }^{25}$ Claudian was an Egyptian Greek who was surely better acquainted with Herodotus than other Latin poets. However, by dint of it he did not show greater specificity as regards Persian wars. This fact can stem from his immersion in Latin literature which was his main source. Another themes from this conflict he touched upon were: crossing of Hellespont and Xerxes Canal (Claud. In Ruf. I 335-336), battle of Salamis (Claud. Manl. 150-152), battle of Thermopylae (Claud. Get. 186-188). 
and of the Xerxes Canal. In Herodotus' narration on Persian wars these motifs served as a proof of enormity of the invading army and the Greek historian imbued his description with moral evaluation castigating the Achaemenid monarch. Yet Claudian - contrary to other Latin poets, e.g. Juvenal, following in Herodotus' footsteps - did not make a slightest allusion to the negative perception of this theme. The abovementioned passage is then a prime example of changing attitude to Xerxes who is no longer a hubristic tyrant but a mere symbol of a commander leading great army. One should bear in mind that it was Stilicho and his army that were equated with Xerxes troops in this passage. ${ }^{26}$ Lack of negative attitude to Persians did not change the fact that - again - the main reason for introducing Iranian themes to the poetic narration was not the interest in these issues per se but the extraordinary circumstances that accompanied them.

Just as Xerxes Alexander the Great was referred to not only in the context of his astonishing campaign (as already noted in the section dedicated to panegyrics), but also as an exemplum of moral virtues and vices. Claudian made use of it in his poem to Hadrianus, one of his carmina minora. Trying to apologise to his addressee for picking a quarrel the poet enumerated mythological and historical heroes who had shown forgiveness to their enemies (1. 13-22). One of them was Alexander who had displayed his magnanimity towards king Darius III:

\section{Pellaeum iuvenem regum flexere ruinae: \\ Dareum famulis manibus doluisse peremptum \\ Fertur et ingenti solatus fata sepulchro; \\ Tradita captivo spatiosior India Poro. \\ (Claud. Carm. min. XXII 16-19)}

Alexander felt pity for defeated Darius and after his death he ordered to bury him in a magnificent tomb, though earlier they had been fighting each other. His behaviour toward the hostile king and his environment became his claim to fame in the later tradition. Darius was juxtaposed with the Indian king Porus (creating thus another Perso-Indian pair) but they were only a background for Alexander's greatness. The Achaemenid monarch, though referred to explicitly by name, stayed really "in the shadow of Alexander" ${ }^{27}$ deprived of any autonomic function. So this passage is a prime example of Claudian's tendency to look at Iranian peoples taking Graeco-Roman experience and into account and perceiving them as passive and unable to act on their own. If

${ }^{26}$ Cf. Bridges 2015: 157-189. However, Bridges does not take Claudian's poetry into account in her monograph.

${ }^{27}$ This phrase is a title of P. Briant's biography of the last Achaemenid - Briant 2015. However, the phrase "in the shadow" could be accurately applied also to other characters from the Iranian history. 
it had not been for the presence of Greeks or Romans in a given passage, Latin authors would not have mention Iranians.

Generally speaking, the Latin poets of Late Antiquity tended to pass over the events of Roman-Persian relations, preferring to focus on Graeco-Persian or Roman-Parthian relations instead, above-mentioned passages from Claudian's poetry being a case in point. One of few exceptions to this rule was a passage from epithalamium of Palladius and Celerina, another carmen minus, referring to the eastern expedition of Carus in $283 \mathrm{AD} .^{28}$ The reason for taking this story into consideration was the participation of Celerina's grandfather, Celerinus, in this event:

\[ \text { Mavortia matris } \]
Nobilitas spoliis armisque exultat avitis
Inmensamque trahit Celerini robore lucem,
Qui quondam Meroen iussus Nilumque tueri,
Cum sibi post obitus et Parthica fulmina Cari
Sceptra daret miles rebusque imponere vellet,
Despexit fremitus et praetulit otia regno.
(Claud. Carm. min. XXV, 70-76)

According to Claudian, after the sudden death of Carus, Celerinus refused to become the emperor putting otium over imperial rule. The historical context of this event, i.e. Carus' unsuccessful campaign, was mentioned only in a short phrase post obitus et Parthica fulmina Cari (1. 74). Surprisingly, this extraordinary campaign during which the emperor had been said to be killed by lightning, was retold as many as three times in Latin poetry, ${ }^{29}$ whereas no other event from the $3^{\text {rd }}$ century relations with Sasanian empire was mentioned even once. The reason for the relative popularity of this event was undoubtedly its uniqueness, by dint of which it could have been treated as a prodigi$u m$. The Iranian world was touched upon only to place the event geographically. There was nothing more than a mere epithet Parthica, which - again - showed that it were not Iranian matters that interested the poet.

Claudian touched upon motifs related to the Iranian customs too. The best example of such a description was his discussion on eunuchs

${ }^{28}$ Another interesting exception is a longer passage from the panegyric on Stilicho's consulship in which Claudian describes his patron's diplomatic mission to Persia. Although this description cannot be treated as a trustworthy evidence for relations between both empires, nevertheless it touches upon the problem of Roman-Persian diplomacy which became a crucial issue in Late Antiquity (see e.g. Canepa 2009: 122-153). I omit this passage since I put it under scrutiny in other paper - Babnis 2021.

${ }^{29}$ Nemes. Cyn. 70-75; Sid. Carm. XXIII 91-96. However, Nemesianus passed over circumstances of Carus' death (even though he called him divus), probably since he was active on the court of his sons, Carinus and Numerianus. It seems that Nemesianus was not a source of Claudian's account, whereas Sidonius alluded clearly to Claudian. 
in the Roman Empire. This subject was related to the eunuch Eutropius, the villain of Claudian's invective "In Eutropium". The poet considered first the problem of who had invented eunuchs and then of the direction from which they had arrived to the Roman Empire. Needless to say, the associations with such a loathsome creature as Eutropius reflected badly on Iranian world, especially in terms of morality. One of the reasons for "inventing" eunuchs could have been an attempt of Semiramis to hide her female sex (Claud. In Eutr. I 338-342), whereas the second relates with Parthian (i.e. Persian) fondness for young boys:

seu Parthica ferro

Luxuries vetuit nasci lanuginis umbram

Servatoque diu puerili flore coegit

Arte retardatam Veneri servire iuventam.

(Claud. In Eutr. I 342-345)

The poet suggested that castration had been used by Persians so as to stop natural processes of growth and to enable the sexual exploitation of boys. ${ }^{30}$ The whole idea met with Claudian's strong disapproval as a transgression of the natural order of things and as an act of debauchery. The phrase Parthica ... luxuries (1. 342-343) brings to mind a long Graeco-Roman tradition of linking Persians (and Orientals in general) with luxury and tendency to excess in everyday life. The castigation of the whole practice was transferred on Eutropius too, by dint of which he received a set of negative features connected generally with the East. ${ }^{31}$ The burden of stereotypes fell on Eutropius ascribing to him a number of faults in ethnic, sexual and social terms. ${ }^{32}$ This moral infection had - according to the poet - also its political aspect, since rampant eunuchs in the (Eastern) Roman Empire emerged there under Persian influence and it was a deliberate move calculated to weaken Romans morally: Arsacio postquam se regia fastu / Sustulit et nostros corrupit Parthia mores (1. 415-416). Claudian returned then to the moral aspect but expanded it with a reference to the monarchical rule (regia, 1. 415), alluding to the traditionally negative Roman attitude towards reges. ${ }^{33}$ Putting aside the poet's accusations of deliberate action to the detriment of Rome, we can state that he was right as far as Persian influence is concerned. Late Antiquity was an age of exceptional 19.

${ }^{30}$ Cf. Garambois-Vasquez 2007: 155-158; Tougher 2015; Babnis 2020a: 11-13, 17 -

${ }^{31}$ On Eastern aspects of invective against Eutropius see Babnis 2020a.

${ }^{32}$ With this reference Claudian recapitulates some charges against Eutropius that have been already mention in the invective, like being a sexual favourite of his former masters (Claud. In Eutr. I 58-77).

${ }^{33}$ Claudian drew a comparison between the despotic eastern rule in Persia and the ideal rule of princeps civilis embodied by Theodosius the Great and given as an example to follow to Honorius (Claud. IV Cons. 214-220). Advice to the young emperor given by the poet were based on Pliny the Younger panegyric to Trajan - Ware 2013. 
mutual exchange between both empires which were even called "two eyes of the earth". ${ }^{34}$ The belief of Persian hostility towards Rome served the poet to transfer negative connotations to his adversary who as an Oriental, eunuch and ex-slave represented all the vices dangerous to the moral health of the Empire. ${ }^{35}$

Reference to Persia as one of world empires was made in the third book of the panegyric on Stilicho's consulship. Contrary to two first books the third was delivered not in Milan but in Rome which meant different auditory. To adjust to these circumstances Claudian dedicated much more place to the idea of Roma aeterna, a concept so dear to senatorial aristocracy of the old capital. ${ }^{36}$ That being so, the poet introduced a catalogue of empires which eventually had to give way to another one, thus bestowing Rome with world hegemony:

\section{sic Medus ademit}

Assyrio Medoque tulit moderamina Perses;

Subiecit Persen Macedo, cessurus et ipse

Romanis.

(Claud. Cons. Stil. III 163-166)

According to A. Cameron this passage is a conventional element of laudes Romae. ${ }^{37}$ Be that as it may, this phrase is important as it contains the mention of two Iranian empires: Median and Persian, which in line with accounts of Herodotus and Ctesias displaced Assyria as leading world powers. The history of the Middle East (even in such general terms) was hardly ever mooted in the Latin poetry, whereas the Median empire sensu stricto (not the Persian or Parthian empire referred to traditionally as Median) is brought up only by Claudian. ${ }^{38}$ Both Iranian empires were recalled so as to - say - pave the way for Rome's greatness. The poet was not interested in them per se (Me$d u s$ and Perses lack any epithet) but again treated it only marginally as

\footnotetext{
${ }^{34}$ See esp. Canepa 2009.

${ }^{35}$ One should bear in mind that this castigation of Eutropius was directed to the elites of Constantinople too. Eastern Roman Empire's hostility towards Stilicho and his unification plans is to be treated as a major factor here. The poet, however, had to be careful in his attacks, so as not to offend the emperor Arcadius, so his condemnation centred usually around particular politicians. On Claudian's attitude towards Constantinople and the eastern part of the Empire, see Kelly 2012; Babnis 2020a: 19-20.

${ }^{36}$ On detailed analysis of this theme in Claudian see Brodka 1998: 91-118.

${ }^{37}$ Cameron 1970: 342. Cf. Keudel 1970: 128.

${ }^{38}$ Surprisingly, the Late Antique poetry has shown more interest in Median empire. Rutilius Namatianus and Sidonius Apollinaris wrote about it in their poems (Rut. Nam. I 79-90; Sid. Carm. IX 19-37), treating it as a predecessor of Achaemenid Persia. It seems to me that this increased interest in this issue may be explained by the tendency to show one's reading and knowledge of ancient history, even if in this case it was probably not taken from the basic source, i.e. Herodotus. On Herodotus' reception in Latin literature see Racine 2016. On Sidonius education see Horváth 2000.
} 
a part of a greater whole. However, it is not irrelevant that it was Claudian who introduced this topic to the Latin poetry, broadening the image of the Iranian world by its enrichment with another motif.

The last group of references contains short mentions of the Iranian themes that do not play any political role nor go back to the historical events. Although these short passages could be treated as insignificant, they actually show some deeply rooted associations and stereotypes connected with the Iranian world as well as Claudian's acquaintance with the literary tradition, since these patterns has been already employed by previous Latin authors. The poet was able to take from these - sometimes worn-out - motifs something fresh and amusing. A prime example of that kind of conduct is a poem about porcupine, one of several carmina minora concerning animals. Claudian ascribed to this species the ability to shoot its spines in a way similar to the famous Parthian shot:

\section{Interdum fugiens Parthorum more sequentem Vulnerat}

Hinc reor inventum, morem hinc traxisse Cydonas

Bellandi Parthosque retro didicisse ferire

Prima sagittiferae pecudis documenta secutos.

(Claud. Carm. min. IX 21-22, 45-47)

If in 1. 21-22 Claudian only compared the behaviour of porcupine with Parthian way of fighting, then in 1. 45-47 he explicitly stated that men borrowed the whole idea from animals. This humorously taken image (with an epic epithet, sagittifer (1.47) introducing a comic contrast between trivial matter and serious wording) of animal $\pi \rho \tilde{\omega} \tau$ o

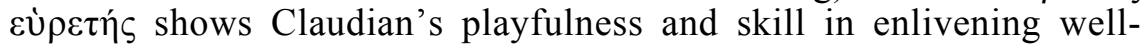
known topics and - in the same time - his particular interest in wild nature. ${ }^{39}$ The skill of porcupine then can be placed among other mirabilia, which resembles in a sense the strong link between Parthians and archery (the mastery of bow and horse was also treated by Romans as something extraordinary).

Claudian made also use of a complex Homeric simile containing reference to the world of Iranian fauna, to the Hyrcanian tigress. The motif he reached for is taken from the scientific writings of Pomponius Mela (Pomp. Mel. III 43), Pliny the Elder (Plin. Nat. hist. VIII 66) and Solinus (Solin. 17, 4), but due to its paradoxographic flavour has a

${ }^{39}$ The Cydonians (i.e. Cretans) were frequently juxtaposed with the Parthians as excellent archers (cf. Claud. IV Cons. 530-531). However, they were not told to shoot arrows back while retreating, so their appearance in the poem is somewhat inconsistent with the reality. Cf. Babnis 2020b: 94, n. 16. 
similar ring to the already mentioned passage on porcupine. ${ }^{40}$ Claudian equates Demeter searching for her daughter with the tigress chasing the hunter who stole her cub:

Arduus Hyrcana quatitur sic matre Niphates, Cuius Achaemenio regi ludibria natos Avexit tremebundus eques: fremit ilia marito Mobilior Zephyro totamque virentibus iram Dispergit maculis timidumque hausura profundo Ore virum vitreae tardatur imagine formae. (Claud. Rapt. III 263-268)

Hyrcania, a region in northern Iran near the Caspian Sea, was famous for its big cats: lions and tigers. ${ }^{41}$ These predators were mentioned in the Latin poetry as well but never in such a detailed way. Claudian not only introduced the idea of impregnation by the wind (marito ... Zephyro, 1. 265-266), but also added another mirabile: the hunter uses a mirror to slow down the tigress. From the point of view of describing the Iranian world, noteworthy is the fact that tiger cubs are stolen to be given to the Persian king. Fictional as it is, this statement may show the poet's acquaintance with the role of hunting in the Iranian culture, in which the king was frequently shown as a great hunter. ${ }^{42}$ However, generally speaking, the entire passage serves clearly as a mere ornament lacking geographical precision but catching reader's attention by use of exotic and unusual imagery, which is not surprising in mythological poem like "De raptu Proserpinae".

Claudian is the poet who made use of Iranian themes relatively often, touching upon them both in his political and non-political poetry. As he lived and composed in the western part of empire lacking any contacts with Sasanian Persia we may suppose that the frequency of references to these issues should be lower. This, however, is not the case. Claudian mentioned Iranian topics 38 times altogether, giving way only to Lucan and - which is also not without significance - being a model to follow for Sidonius Apollinaris. Generally, the Latin poets used to mention rather limited number of motifs related to the Iranian world focusing on Roman-Parthian (later Roman-Persian) relations and subjects being extraordinary in one way or another. In majority of cases

${ }^{40}$ Apart from this passage Claudian refers to the Iranian fauna in Rapt. I 17-18. In earlier poetry we come across mentions of wild cats and hunting dogs (e.g. Verg. Aen. IV 367; Gratt. 161-170; Stat. Theb. V 204).

${ }^{41}$ It is possible that classical writers referred to now extinct species of Caspian tiger (Panthera tigris virgata) who lived in the areas of northern Iran.

${ }^{42}$ Already in the Achaemenid times we find a lot of information about so called $\pi \alpha \rho \alpha ́ \delta \varepsilon 1 \sigma o l$, i.e. palaces with hunting grounds for the king and aristocracy. Sasanians followed their example. The extant hunting relief in Taq-e Bostan, silver plates with hunting scenes, as well as a tradition about the hunting mania of the king Wahram V Gur being a case in point - see also Canepa 2009: 31, 157-162, 174-176; Babnis 2020b: 457. 
Claudian followed suit, concentrating on issues strongly connected with contacts between Iranians and Romans or relating to something extraordinary. However, by adding some new motifs or by expanding on the already existing ones he developed the inherited image.

The references to the Iranian themes can be divided into three groups. First of them shows Persia as a place to be conquered in the future when Honorius comes of age. As an easy prey for the Roman expansion Persia is not infrequently presented as wealthy, adding economic factor to the idea of expansion. Usually it serves only as a part of the Eastern world and is very often paired with India, thus showing the connection with idea of imitatio Alexandri. The second group of references relates to the past events. This category contains motifs from the history of Graeco-Persian wars and from later Roman-Parthian and Roman-Persian relations. The chronology of the mentioned events stretches from the Persian Wars of $5^{\text {th }}$ century BC up to the end of $4^{\text {th }}$ century $\mathrm{AD}$, i.e. almost to the present day of the poet and on that account has frequently a political note. In line with more general tendencies of Latin poetry, Parthians and Persians are treated as enemies wanting to weaken the Roman Empire. The third group of references is made up of - usually short - mentions serving as ornaments and lacking political, historical and moral dimension.

The majority of references is based on literary sources. ${ }^{43}$ Even if some motifs had not been touched upon earlier in the Latin poetry, they were present in prose. Therefore in mentioning Iranian themes Claudian was influenced by former authors, especially by Vergil, Lucan and Statius from whom he borrowed both motifs and phrases. Claudian's Greek background did not seem to have any impact on his treatment of Iranian issues. Even though he certainly had easier access to such works like Herodotus' "Histories" or Xenophon's "Anabasis" one cannot find their stronger resonance. Claudian's skilful employment of Latin sources shows a great deal of talent and poetic ability, making him, a poet from Egypt, a true successor of great traditions of the Latin poetry and himself a model for future authors.

${ }^{43}$ Cf. Chauvot 1998: 329. 


\title{
BIBLIOGRAPHY
}

\author{
Primary sources
}

Claudii Claudiani carmina (1985). J.B. Hall (ed.). Leipzig, Teubner.

\section{Secondary sources}

Babnis, T. (2019). "The River Araxes in the Roman Poetry". Classica Cracoviensia 22, pp. 7-46.

Babnis, T. (2020a). "Eutropius as an Oriental. Building the Invective with References to Orient in the First Book of Claudian's In Eutropium". Classica Cracoviensia 23, pp. 7-23.

Babnis, T. (2020b). Obraz świata irańskiego w poezji rzymskiej (III w. p.n.e. - VI w. n.e.). Kraków, Uniwersytet Jagielloński.

Babnis, T. (2021). "Idem aliter, czyli o dwóch opisach dyplomatycznej podróży do Persji w poezji późnego antyku (Claud. Cons. Stil. I 51-68; Sid. Carm. II 75-88)”. Collectanea Philologica 24 [forthcoming].

Briant, P. (2015). Darius. In the Shadow of Alexander. Cambridge - London, Harvard University Press.

Bridges, E. (2015). Imagining Xerxes. Ancient Perspectives on a Persian King. LondonNew York, Bloomsbury.

Brodka, D. (1998). Die Romideologie in der römischen Literatur der Spätantike. Frankfurt am Mein, Peter Lang.

Cameron, A. (1970). Claudian. Poetry and Propaganda at the Court of Honorius. Oxford, Clarendon Press.

Canepa, M.P. (2009). The Two Eyes of the Earth. Art and Ritual of Kingship between Rome and Sasanian Iran. Berkeley - Los Angeles - London, University of California Press.

Chauvot, A. (1998). Opinions romaines face aux barbares au $I^{e}$ siècle ap. J.-C. Paris, De Boccard.

Coombe, C. (2018). Claudian the Poet. Cambridge, Cambridge University Press.

Döpp, S. (1980). Zeitgeschichte in Dichtungen Claudians. Wiesbaden, Franz Steiner Verlag.

Garambois-Vasquez, F. (2007). Les invectives de Claudien. Une poétique de la violence. Bruxelles, Latomus.

Georges, P.B. (1994). Barbarian Asia and the Greek Experience. From the Archaic Period to the Age of Xenophon. Baltimore - London, John Hopkins University Press.

Guipponi-Gineste, M.-F. (2010). Claudien. Poète du monde à la cour d'Occident. Paris, De Boccard.

Hall, E. (1989). Inventing the Barbarian. Greek Self-Definition Through Tragedy. Oxford, Oxford University Press.

Horváth, Á.T. (2000). "The Education of Sidonius Apollinaris in the Light of his Citations". Acta Classica Universitatis Scientiarum Debreceniensis 36, 151-162.

Isaac, B. (2004). Invention of Racism in Classical Antiquity. Princeton - Oxford, Princeton University Press.

Kelly, G. (2012). "Claudian and Constantinople”, in: L. Grig, G. Kelly (ed.), Two Romes. Rome and Constantinople in Late Antiquity. Oxford, Oxford University Press, 241-264.

Kelly, G. (2013). “Sidonius and Claudian”, in: J.A. van Waarden, G. Kelly (ed.). New Approaches to Sidonius Apollinaris. Leuven - Paris - Walpole, Peters, 171-194. 
Keudel, U. (1970). Poetische Vorläufer und Vorbilder in Claudians De consulatu Stilichonis. Göttingen, Vandenhoeck \& Ruprecht.

Kühnen, A. (2008). Die imitatio Alexandri in der römischen Politik. 1. Jh. v. Chr. - 3. Jh. n. Chr. Münster, Rhema.

Lerouge, Ch. (2007). L'image des Parthes dans le monde gréco-romain. Du début du I ${ }^{\text {er }}$ siècle av. J.-C. jusqu'à la fin du Haut-Empire romain. Stuttgart, Franz Steiner Verlag.

McCormick, M. (1986). Eternal Victory. Triumphal Rulership in Late Antiquity, Byzantium and the Early Medieval West. Cambridge, Cambridge University Press.

Paratore, E. (1966). "La Persia nella letteratura latina", in: Atti del convegno sul tema: La Persia e il mondo greco-romano. Roma, Accademia Nazionale dei Lincei, 505558.

Racine, F. (2016). "Herodotus' Reputation in Latin Literature from Cicero to the $12^{\text {th }}$ Century", in: J. Priestley, V. Zali (ed.), Brill's Companion to the Reception of Herodotus in Antiquity and Beyond. Leiden - Boston, Brill, 193-212.

Rosivach, V.J. (1984). “The Romans' View of the Persians”. The Classical World 78/1, 1-8.

Schindler, C. (2009). Per carmina laudes. Untersuchungen zur spätantiken Verspanegyrik von Claudian bis Coripp. Berlin - New York, Walter de Gruyter.

Tougher, S. (2015). "Eunuchs in the East, Men in the West? Dis/unity, Gender and Orientalism in the Fourth Century", in: R. Dijkstra, S. van Poppel, D. Slootjes (ed.), East and West in the Roman Empire of the Fourth Century. An End to Unity?, Leiden - Boston, Brill, 147-163.

Ware, C. (2012). Claudian and the Roman Epic Tradition. Cambridge, Cambridge University Press.

Ware, C. (2013), "Learning from Pliny. Claudian's Advice to the Emperor Honorius". Arethusa 46/2, 313-331. 